\title{
Crops grown on set-aside land bring wild birds back to the fields
}

\author{
Monitoring is under way, and results so far are promising.
}

Sir - David Kleijn and colleagues report (Nature 413, 723-725; 2001) that a Dutch scheme designed to improve agricultural grasslands for wading birds had failed more birds were found on nearby conventionally managed grass fields and call for scientific monitoring of the effects of similar schemes elsewhere.

Just this type of monitoring programme is being conducted in the United Kingdom, showing that the 'wild bird cover option' - the growing of certain crops on set-aside ground to benefit declining farmland bird populations - can indeed be successful.

The Game Conservancy Trust and the British Trust for Ornithology, supported by the Department for Environment, Food and Rural Affairs (DEFRA), are monitoring various crop mixtures sown on more than 100 farms across southern and central England, with the aim of determining which crops are preferred by the many species of birds encountered. Experimental work will confirm birds' preferences and inform on the amount of cropping needed. Similar work is under way in Scotland.

So far, the findings show that all crop types studied support densities of farmland birds that are orders of magnitude higher than nearby conventional fields, with the biennial brassica kale (Brassica napus) and quinoa (Chenopodium quinoa), a member of the the beet family — both seed-bearing plants - being the preferred crops for most birds. Given suggestions that the decline of farmland birds could be due to the recent loss of over-winter food supplies, the implementation of prescriptions such as 'wild bird cover' could have a major impact on bird populations in the United Kingdom and, no doubt, elsewhere.

Chris Stoate ${ }^{\star}$, Dave Parish $\dagger$

${ }^{*}$ Allerton Research and Education Trust, Loddington House, Loddington, Leicestershire LE7 9XE, UK

†The Game Conservancy Trust, 21 South Esk Road, Tannadice, Angus DD8 3SH, Scotland west. To call this "yielding to the politics of an uncivil society" is amazing nihilism. I do not understand such ignorance in our academic community.

Arno Arrak

5 Chatham Place, Dix Hills, New York 11746, USA

\section{Schemes are monitored and effective in the UK}

Sir — Kleijn et al. call for reliable evaluation of agri-environment schemes across Europe $^{1}$, after concluding that schemes in the Netherlands did not increase the numbers of target wildlife species.

Detailed monitoring of this type has been undertaken in the United Kingdom since 1987. The results of various surveys have been published in books (see, for example, ref. 2) and journals (for example, ref. 3) and - for England - on the Department for Environment, Food and Rural Affairs' website (www.defra.gov.uk/ erdp/erdpfrm.htm).

These reports and papers demonstrate that, in general, the UK schemes have maintained biodiversity, and show some limited enhancement in wildlife. When monitoring has revealed problems, management prescriptions given to farmers have been changed to improve the effectiveness of the scheme concerned.

Although the UK government and its agencies have spent considerable sums of money to determine the efficacy of agricultural-environment schemes in the United Kingdom, governments are often reluctant to fund adequate monitoring because of the administrative costs - the more money that is spent on monitoring, the less there is to advise farmers.

Unfortunately, the costs of administering European agricultural-environment schemes have to be borne by the country concerned, and are not subsidized by the European Union (EU). If the EU is willing to pay for monitoring, it will help to ensure the adequate assessment, and indeed the comparison, of such schemes.

Peter D. Carey

Centre for Ecology and Hydrology, Monks Wood, Abbots Ripton, Huntingdon PE28 2LS, UK

1. Kleijn, D., Berendse, F., Smit, R. \& Gilissen, N. Nature 413, 723-725 (2001).

2. Sheldrick, R. D. ed. Grassland Management in Environmentally Sensitive Areas (British Grassland Society, Lancaster, 1997).

3. Peach, W. J. L., Lovett, L. J., Wotton, S. R., Jeffs, C. Biol. Conserv. 101,361-373 (2001).

\section{War: no time for dissent}

Sir - Your correspondent Morton K. Brussel is wrong ("Don't use terrorism as an excuse for militarism"; Nature 414, 249; 2001). We are not in a new war promoted by the Bush administration. We are responding to an unprovoked attack that is a threat to civilized life. This is understood by the whole world, and we have the support of all the leading powers, east and

\section{Church backing depends on ethical use of animals}

Sir-As reported in your News story

"Vatican approves use of animal transplants 'to benefit humans"' (Nature 413, 445; 2001), the Vatican's Pontifical Academy for Life has recently organized several meetings to discuss the science, theology, ethics, law and procedures for xenotransplantation (see www.academiavita.org for a complete account and references). Here, we draw attention to the Vatican's conclusions, and offer a Catholic view on two current debates.

The Vatican sees three issues as critical from a theological perspective. First, man has a right and duty to act within and on the created order, making use of other creatures to achieve the final goal of all creation: the glory of God through the promotion of man.

Second, in xenotransplantation the service of animals to man represents a totally new application that is not in conflict with the order of creation. Humans must answer to the Creator for the manner in which they treat animals. The sacrifice of animals is justified only if it is required to achieve an important benefit for man, including experiments on animals and/or genetic modification of them.

Third is the question of whether an animal organ in the human body modifies a person's identity. Although transplantation of the encephalon or the gonads, which are integral to personal identity, can never be morally legitimate, that of purely functional organs is legitimate.

Finally, we mention two ethical issues. First, the vast healthcare resources that would be used for xenotransplantation are justified by the urgent need to save the lives of patients. Second is the ethical need to acquire correct information on potential benefits and risks. This should be communicated to the public. By public discussion and debate, society should help to identify the conditions under which it is acceptable to invest resources and hope in this new therapeutic approach, in the light of scientific uncertainties and the urgent need for more organs for transplantation. Archbishop Monsignor Elio Sgreccia ${ }^{\star}$, Don Maurizio Calipari ${ }^{\star}$, Marialuisa Lavitrano $\dagger$ ${ }^{*}$ Pontifical Academy for Life, Via della Conciliazione 3, 00120 Vatican City, Italy $\dagger$ Department of Experimental Medicine, University of Milano-Bicocca, Via Cadore 48, 20052 Milan, Italy 